\title{
Synthesis of ethyl-3-amino-1-aryl-1H-benzo[f]chromeme-2-carboxylate derivatives promoted by DMAP
}

\author{
Abbas Ghasemian Zeidanlu ${ }^{a^{*}}$, Safoora Sheikh ${ }^{\mathrm{b}}$, Jalil Lari ${ }^{\mathrm{a}}$ and Hooshang Vahedi ${ }^{\mathrm{a}}$
}

${ }^{a}$ Department of Chemistry, Payame Noor University, Mashhad, 91735-433, Iran

${ }^{b}$ Department of Chemistry, Faculty of Science, University of Birjand, Birjand, 97179-414 Iran

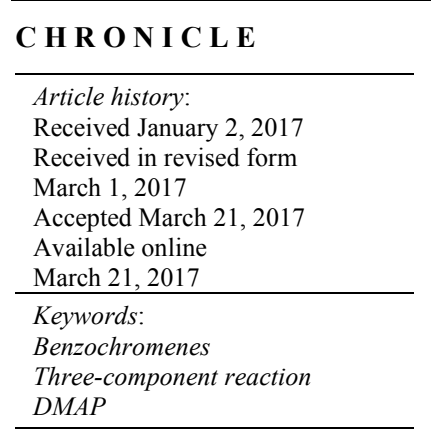

\section{A B S T R A C T}

\begin{abstract}
An efficient route, convenient and environmentally friendly procedure for the synthesis chromenes derivatives have been developed via a three-component coupling and one-pot reactions of various aromatic aldehyde with malononitrile or ethyl cyanoacetate and phenols in the presence N,N-dimethylpyridin-4-amine (DMAP) in reflux conditions. In simple reaction conditions, the use of DMAP is explored as an easy workup and a green catalyst for the onepot three-component synthesis ethyl 3-amino-1-aryl-1H-benzo[f]chromene-2-carboxylate derivatives.
\end{abstract}

\section{Introduction}

Chromenes derivatives are very important biologicals that occur widely in natural products. Chromenes derivatives significant heterocycles that are known to have multiple biological activities ${ }^{1}$ for instance, antibacterial, ${ }^{2}$ antitumor, ${ }^{3}$ sex pheromonal, ${ }^{4}$ antimicrobial, ${ }^{5} \mathrm{TNF}$-a inhibitory, ${ }^{6}$ anticancer, ${ }^{7}$ antifungal, ${ }^{8}$ estrogenic, ${ }^{9}$ antiviral ${ }^{10}$ and anti-HIV. ${ }^{11}$ Such compounds have also been applied in pigments, and insecticides ${ }^{12}$ and therefore, a number of methods and catalysts have been reported for the synthesis of chromene derivatives such as, a [1-(n-butyl)-3-methylimidazolium hydroxide ([bmim]$\mathrm{OH})] / \mathrm{H}_{2} \mathrm{O} /$ reflux, $^{13}$ Triton B/EtOH/rt, ${ }^{14} \mathrm{~K}_{2} \mathrm{CO}_{3} / \mathrm{H}_{2} \mathrm{O} / \mathrm{MW}$ irradiation, ${ }^{15} \mathrm{MCM}-41-\mathrm{NH}_{2} / \mathrm{H}_{2} \mathrm{O} / 80{ }^{\circ} \mathrm{C},{ }^{16}$ CTACl/ $\mathrm{H}_{2} \mathrm{O} /$ reflux ${ }^{17}$ CTABr/us/ $\mathrm{H}_{2} \mathrm{O} / \mathrm{rt},{ }^{18} \mathrm{~K}_{3} \mathrm{PO}_{4} .3 \mathrm{H}_{2} \mathrm{O} /$ solvent free, ${ }^{19}$ piperazine/neat/ MW irradiation, ${ }^{20}$ tetramethylguanidine/neat $/ \mathrm{rt},{ }^{21} \quad \mathrm{H}_{14}\left[\mathrm{NaP}_{5} \mathrm{~W}_{30} \mathrm{O}_{110}\right] / \mathrm{H}_{2} \mathrm{O} / \mathrm{reflux},{ }^{22} \mathrm{CuSO}_{4} .5 \mathrm{H}_{2} \mathrm{O} /$ $\mathrm{H}_{2} \mathrm{O}$ /reflux, ${ }^{23}$ methanesulfonic acid/ $\mathrm{CH}_{3} \mathrm{CN} /$ reflux, ${ }^{24} \mathrm{KF}-\mathrm{Al}_{2} \mathrm{O}_{3} / \mathrm{EtOH} / 80^{\circ} \mathrm{C},{ }^{25}$ potassium phthalimide-Noxyl/ $\mathrm{H}_{2} \mathrm{O} /$ reflux, ${ }^{26}$ the nanostructured diphosphate $\mathrm{Na}_{2} \mathrm{CaP}_{2} \mathrm{O}_{7 /} \mathrm{H}_{2} \mathrm{O} /$ reflux, ${ }^{27}$ nano polypropylenimine dendrimer (DAB-PPI-G $)_{1}$ ) /solvent free $/ 110^{\circ} \mathrm{C}^{28} \mathrm{DBU},{ }^{29} \mathrm{KF} /$ solvent free $/ 110^{\circ} \mathrm{C},{ }^{30}$ and $\mathrm{Ca}(\mathrm{OH})_{2} / \mathrm{MeOH} / \mathrm{rt} .{ }^{31} \mathrm{Many}$ of the above methods have their own advantages. However, several of these methods suffer from certain drawbacks such as use of expensive catalyst, prolonged reactions times, use of volatile or hazardous organic solvents, tedious workup conditions, use of extra energy source,

* Corresponding author. Tel/Fax: +98 (51) 47224994; Tel.: +98 (915) 6133767 
employment of large amount of catalyst and harsh reaction conditions. The present work represents a new method for the synthesis of chromene derivatives using DMAP as catalyst and co-solvent (additive), as a rapid convenient method with suitable yields. The point is which lead to higher purity of the products in compare with conventional method.

\section{Results and Discussion}

In continuation of our efforts toward the development of greener methodologies, ${ }^{32-38}$ we report here in a simple, clean, and environmentally friendly process for the synthesis of ethyl-3-amino-1-aryl-1Hbenzo[f]chromene-2-carboxylate derivatives by reaction of various aromatic aldehydes with malononitrile or ethyl cyanoacetate and phenols ( $\alpha$-naphthol or $\beta$-naphthol ) in the presence DMAP, as catalyst and co-solvent (Scheme 1).

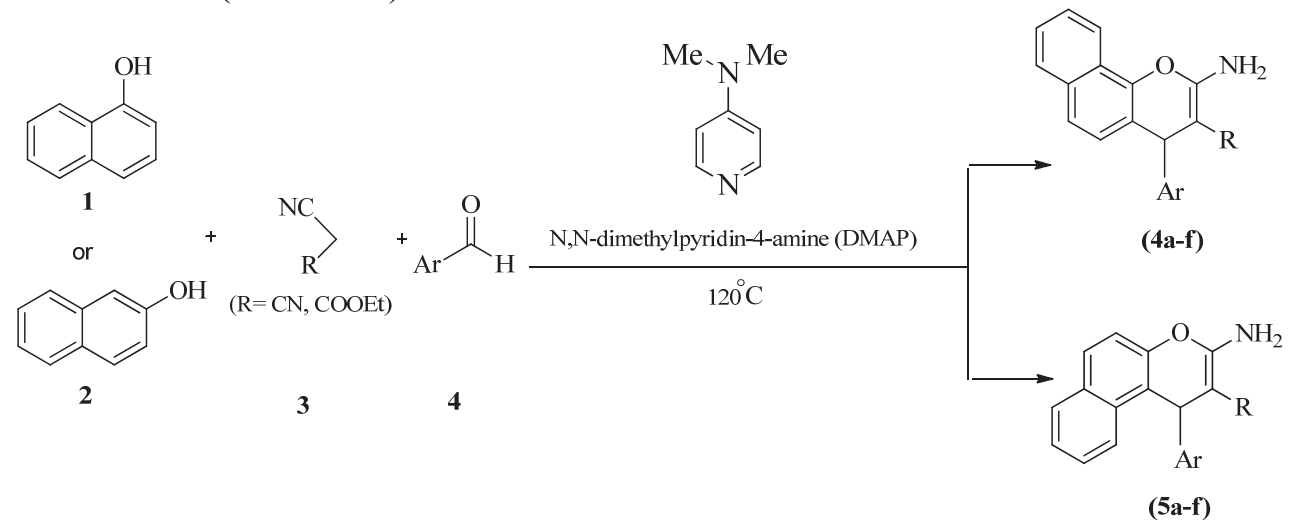

Fig. 1. One-pot synthesis of ethyl 3-amino-1-aryl-1H-benzo[f]chromene-2-carboxylate derivatives promoted by DMAP.

In the beginning, we chose three-component reaction via ethyl cyanoacetate ( $1 \mathrm{mmol}), p$ nitrobenzaldehyde (1 mmol), and 2-naphthol $(1 \mathrm{mmol})$ (5a) as a model to determine the optimal reaction conditions. Reaction was performed in the presence of varying amounts of DMAP and at different temperatures. The best result is achieved in $0.5 \mathrm{mmol}$ of DMAP at $120^{\circ} \mathrm{C}$ (Table 1, Entry 3). Also reaction was carried out in absence of the catalyst and was not observed product even after $5 \mathrm{~h}$ (Table 1, Entry 3). A summary of the optimization experiments is provided in Table 1.

Table. 1. Screening of the Reaction Conditions for the Synthesis of (5a).

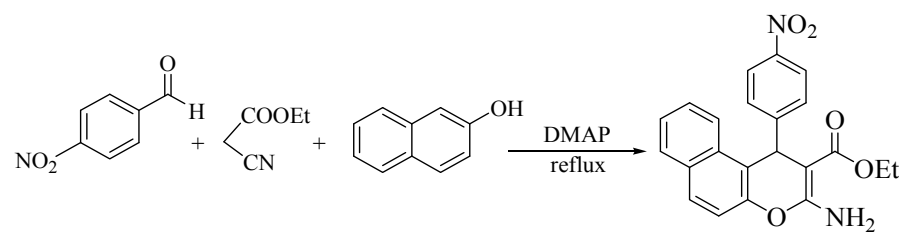

\begin{tabular}{ccccc}
\hline Entry & DMAP $(\mathbf{m o l} \mathbf{\%})$ & Temperature $\left.\mathbf{~}^{\circ} \mathbf{C}\right)$ & Time (min) & Yield $^{\mathbf{1}}(\mathbf{\%})$ \\
\hline $\mathbf{1}$ & 10 & 100 & 20 & 76 \\
$\mathbf{2}$ & 10 & 110 & 20 & 80 \\
$\mathbf{3}$ & 10 & 120 & 20 & 91 \\
$\mathbf{4}$ & 10 & 130 & 20 & 85 \\
$\mathbf{5}$ & 15 & 120 & 20 & 90 \\
$\mathbf{6}$ & 5 & 120 & 20 & 81 \\
$\mathbf{7}$ & 10 & $\mathrm{rt}$ & 300 & 2 \\
$\mathbf{8}$ & - & 120 & 300 & -2 \\
\hline
\end{tabular}

\footnotetext{
${ }^{1}$ Isolated yields; ${ }^{2}$ No reaction.
} 
After optimization of the reaction conditions, we studied the generality of these conditions to other substrates. By using this method, different kinds of various aromatic aldehydes compounds were reacted with malononitrile or ethyl cyanoacetate and phenols to produce the corresponding chromenes derivatives under reflux conditions (Table 2).

Table. 2. One-pot synthesis of ethyl-3-amino-1-aryl-1H-benzo[f]chromeme-2-carboxylate derivatives under reflux conditions.

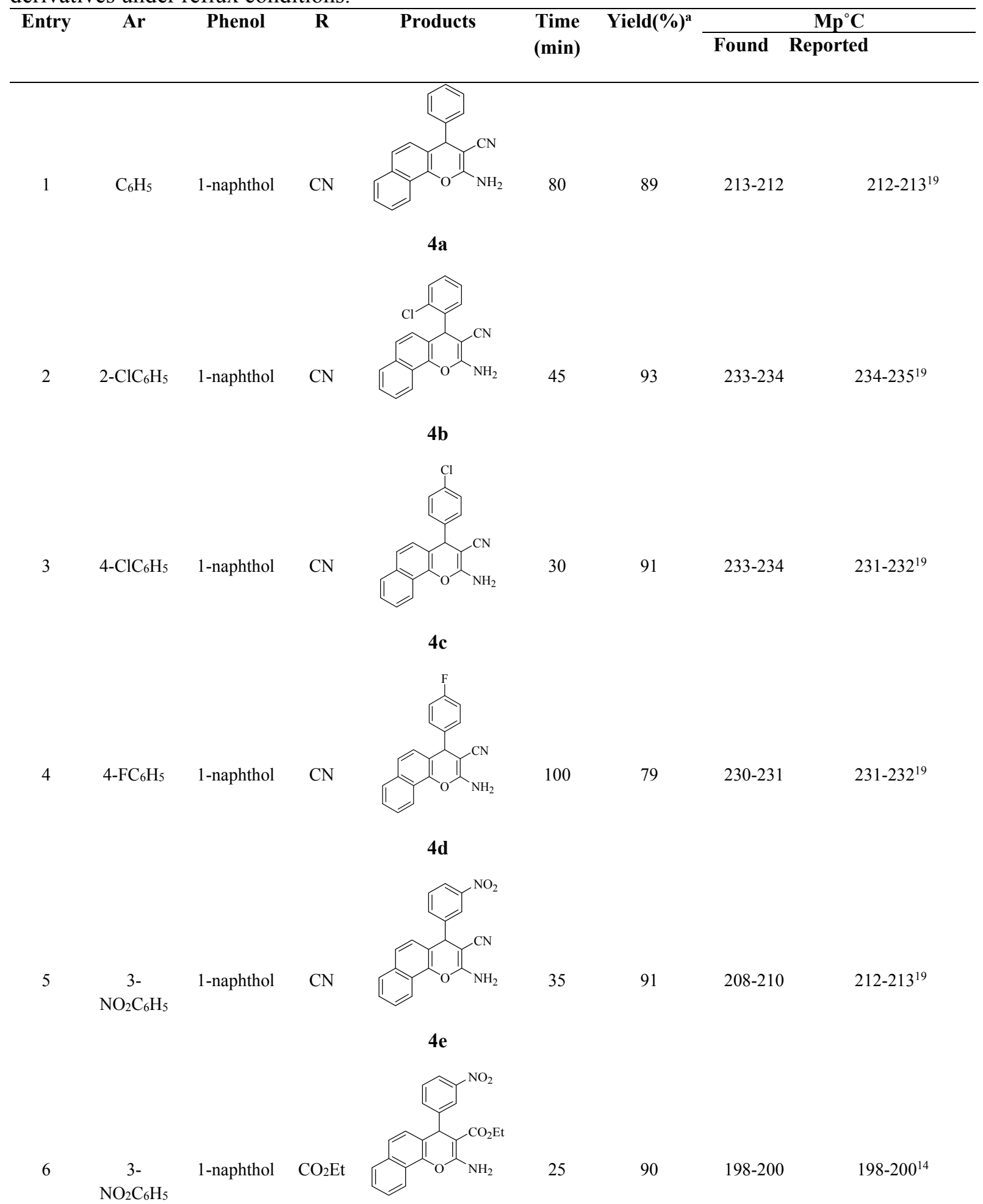




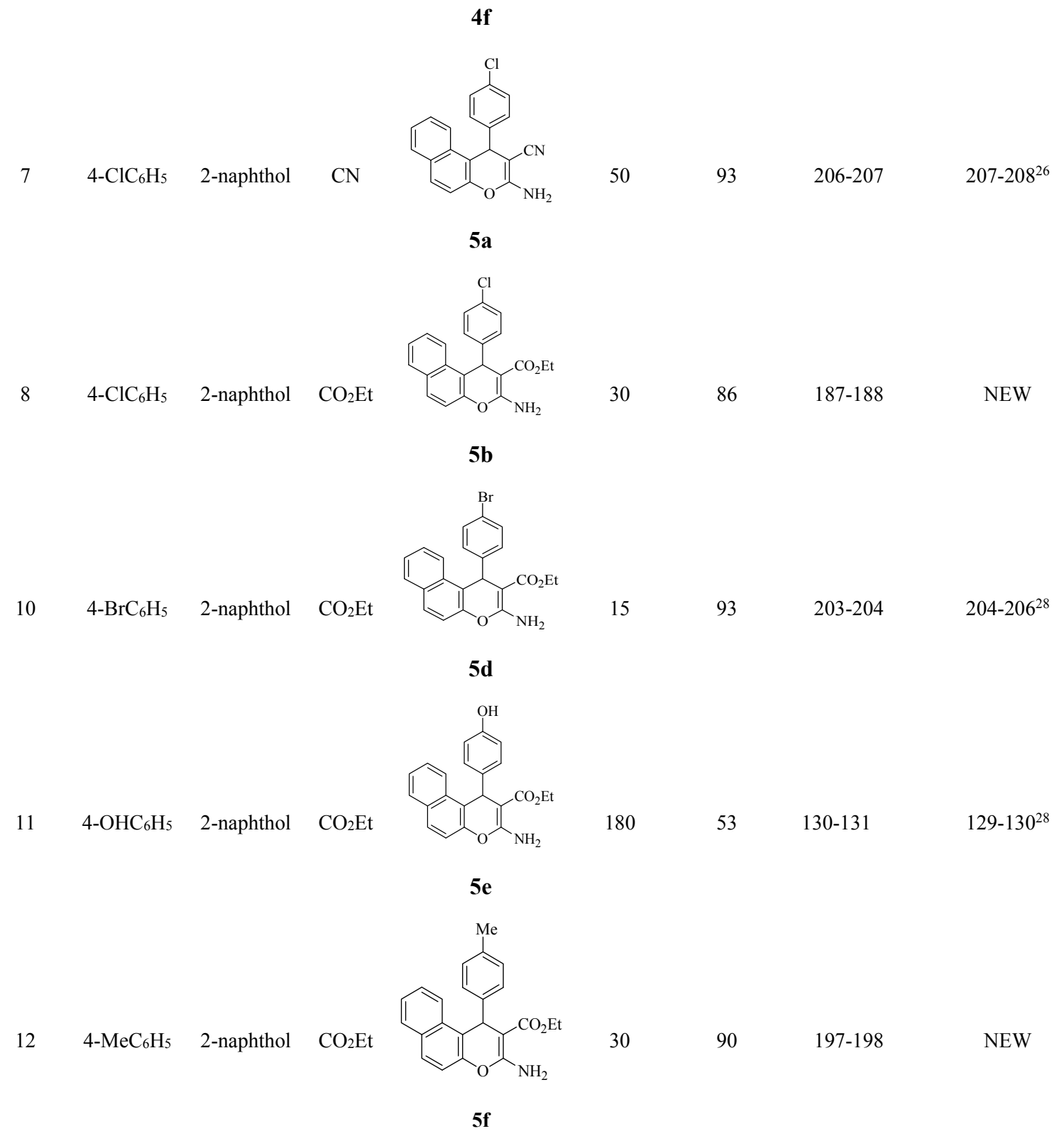

${ }^{1}$ Isolated yields

Finally, to show the merit of the present work, we summarized the results for the synthesis of chromenes derivatives obtained by other workers (Table 3). In contrast with other existing methods, the present methodology offers several advantages such as higher yields, a simple procedure, easy synthesis, simple work-up, does not require either hazardous acids or harsh reaction and greener conditions using DMAP as an efficient catalyst (Table 3).

\section{Conclusions}

In summary, we have developed an efficient and environmentally friendly method for the synthesis of 2-amino-2-chromenes in high yield, by use DMAP, as catalyst and co-solvent (additive). In contrast to the existing methods using potentially hazardous catalysts/additives, these procedures provide several advantages such as cleaner reactions, does not require either hazardous acids or harsh reaction, easier work-up, and an eco-friendly and promising strategy. 
Table. 3. Comparison of methods for the synthesis of chromenes derivatives.

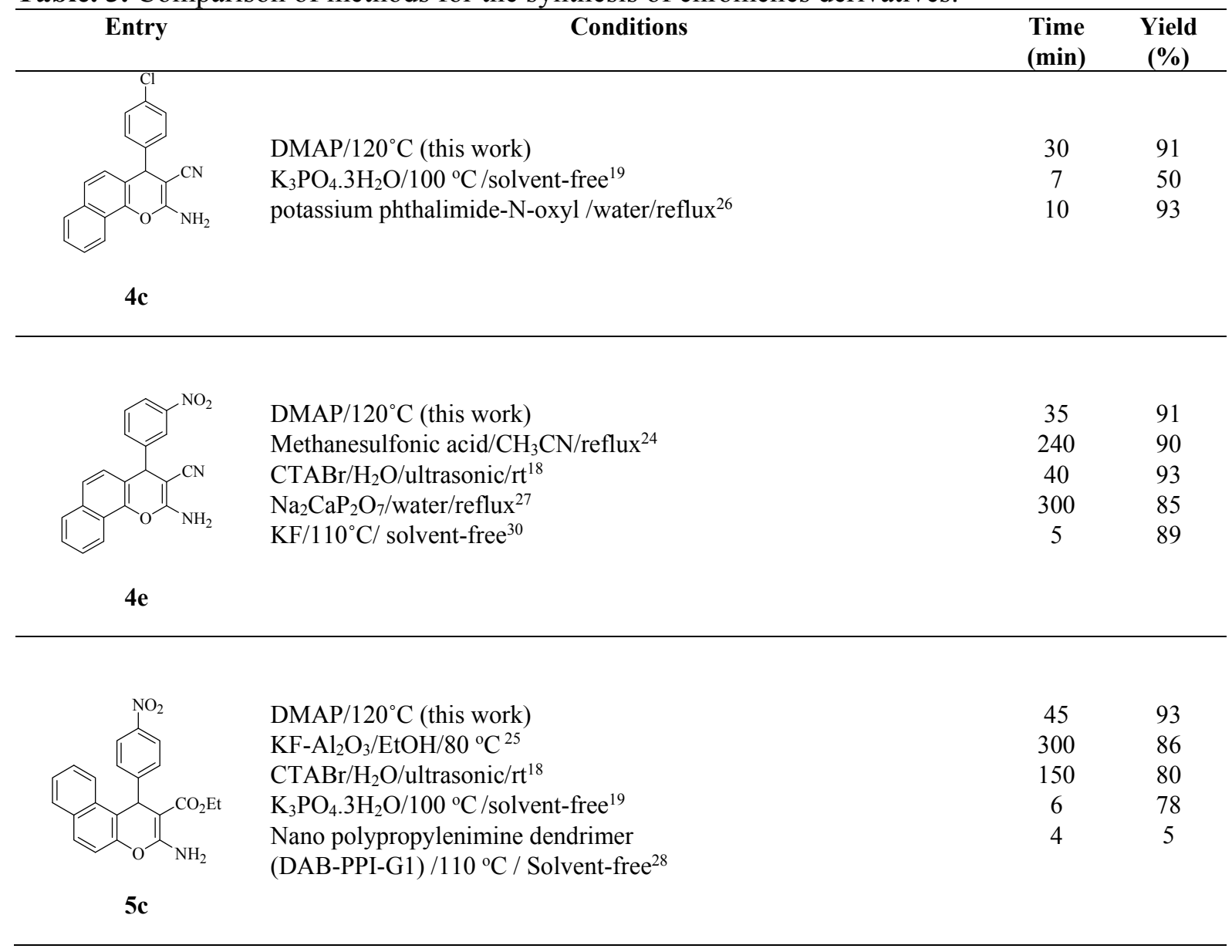

\section{Acknowledgements}

The authors are thankful to research council of Payame Noor University of mashhad and Hakim Sabzevari University for financial support.

\section{Experimental}

\subsection{Generel}

All the chemicals required for the synthesis of cheromene derivatives were purchased from Merck Company. A Bruker (DRX-400 AVANCE) NMR instrument was used to record the ${ }^{1} \mathrm{H}$ NMR and ${ }^{13} \mathrm{C}$ NMR spectra. All NMR spectra were determined in $\mathrm{CDCl}_{3}$ at ambient temperature; chemical shifts have been expressed in ppm. The IR spectra were recorded on a Shimadzu 8400 instrument (the samples as $\mathrm{KBr}$ disks for the range $400-4000 \mathrm{~cm}^{-1}$ ). Melting points were recorded with Electrothermal 9100 apparatus. Thin-layer chromatography was performed on Kieselgel $60 \mathrm{GF}_{254}$ and visualization was accomplished by UV Lamp or iodine flask. Elemental analysis was carried out on a Thermo Finnigan Flash EA microanalyzer, and the results were found to match satisfactorily with the calculated and observed values.

\subsection{General procedure for the synthesis of cheromene derivatives (4a-f and $5 a-f)$.}

To a mixture of various aldehydes, 1-naphthol or 2-naphlhol $(5 \mathrm{mmol})$, ethyl 2-cyanoacetate or malononitril $(5 \mathrm{mmol})$ and DMAP $(0.5 \mathrm{mmol})$ in reflux conditions was stirred magnetically at $120^{\circ} \mathrm{C}$ 
for an appropriate time as mentioned in Table 2. Completion of the reaction was indicated by TLC (hexane:ethyl acetate, 8:2), after completion, appropriate amounts of hot EtOH (96\%) was added and the mixture stirred for $10 \mathrm{~min}$. Next, the resulting crude product was poured into crushed ice and the solid product, which separated was filtered, recrystallized from ethanol $(96 \%, 3 \mathrm{ml})$ to get pure cheromene derivatives (4a-f and 5a-f).

4.3 Physical and Spectral Data for New Compounds

Ethyl 3-amino-1-(4-chloro phenyl)-1H-benzolflchromene-2-carboxylate (5b). White crystals, M.p. $187-188^{\circ} \mathrm{C}$; IR $\left(\mathrm{KBr}, \mathrm{cm}^{-1}\right)$ : 3328-3467, 3078, 2977, 1670, 1639, 1504, 1072, $1222 \mathrm{~cm}^{-1}$; ${ }^{1} \mathrm{H}$ NMR $\left(\mathrm{CDCl}_{3}\right): \delta 1.38\left(\mathrm{t}, 3 \mathrm{H}, \mathrm{CH}_{3}\right), 4.23\left(\mathrm{~m}, 2 \mathrm{H}, \mathrm{CH}_{2}\right), 5.58(\mathrm{~s}, 1 \mathrm{H}, \mathrm{CH}), 6.33\left(\mathrm{br}, 2 \mathrm{H}, \mathrm{NH}_{2}\right) ;{ }^{13} \mathrm{C} \mathrm{NMR}$ $\left(\mathrm{CDCl}_{3}\right): \delta 14.6,36.7,59.7,79.9,159.9,169$. Anal. Calcd. For $\mathrm{C}_{22} \mathrm{H}_{18} \mathrm{ClNO}_{3}$ (379.8): C, 69.57; H, 4.78; N, 3.69; O, 12.64; Cl, 9.33; Found: C, 69.40; H, 4.86; N, 3.55; O, 12.57.

Ethyl 3-amino-1-p-tolyl-1H-benzolflchromene-2-carboxylate (5f). White crystals, M.P. 197-198 ${ }^{\circ} \mathrm{C}$; IR $\left(\mathrm{KBr}, \mathrm{cm}^{-1}\right): 3332-3467,3013,2927,1670,1639,1504,1072,1222 \mathrm{~cm}^{-1} ;{ }^{1} \mathrm{H} \mathrm{NMR}\left(\mathrm{CDCl}_{3}\right): \delta$ $1.4\left(\mathrm{t}, 3 \mathrm{H}, \mathrm{CH}_{3}\right), 2.4\left(\mathrm{~s}, 3 \mathrm{H}, \mathrm{CH}_{3}\right), 4.2\left(\mathrm{~m}, 2 \mathrm{H}, \mathrm{CH}_{2}\right), 5.5(\mathrm{~s}, 1 \mathrm{H}, \mathrm{CH}), 6.3\left(\mathrm{br}, 2 \mathrm{H}, \mathrm{NH}_{2}\right) ;{ }^{13} \mathrm{C}^{\mathrm{N} M R}$ $\left(\mathrm{CDCl}_{3}\right) \delta$ ppm: 14.6, 21, 36.7, 59.7, 80.5, 160, 169.3; Anal. Calcd. For $\mathrm{C}_{23} \mathrm{H}_{21} \mathrm{NO}_{3}$ (359.4): C, 76.86; H, 5.89; N, 3.90; O, 13.35; Found: C, 76.64; H, 5.93; N, 3.78; O,13.16.

\section{References}

1 Kang Y., Du Y., and Jin Z. (2003) Total synthesis of the highly potent anti-HIV natural product daurichromenic acid along with its two chromane derivatives. Org. Lett., 5 (23) 4481-4484.

2 Kidwai M., Saxena S., Rahman Khan M. K., and Thukral S. S. (2005) Aqua mediated synthesis of substituted 2-amino-4H-chromenes and in vitro study as antibacterial agents. Bioorg. Med. Chem. Lett., 15 (19) 4295-4298.

3 Lagisetti C., Pourpak A., Jiang Q., Cui X., Goronga T., Morris S. W., and Webb T. R. (2008) Antitumor compounds based on a natural product consensus pharmacophore. J. Med. Chem., 51 (19) 6220-6224.

4 Bianchi G., and Tava A. (1987) Synthesis of (2R)-(+)2, 3-Dihydro-2, 6-dimethyl-4H-pyran-4-one, a homologue of pheromones of a species in the Hepialidae family. Agric. Biol. Chem., 51, 20012002.

5 Khafagy M. M., El-Wahab A. H. A., Eid F. A., and El-Agrody A. M. (2002) Synthesis of halogen derivatives of benzo [h] chromene and benzo [a] anthracene with promising antimicrobial activities. II Farmaco., 57 (9) 715-722.

6 Cheng J. F., Ishikawa A., Ono Y., Arrhenius T. and Nadzan A. (2003) Novel Chromene Derivatives as TNF- $\alpha$ Inhibitors. Bioorg. Med. Chem. Lett., 13 (21) 3647-3650.

7 Mun J., Jabbar A. A., Devi N. S., Liu Y., Van Meir E. G., and Goodman M. M. (2012) Structureactivity relationship of 2,2-dimethyl-2H-chromene based arylsulfonamide analogs of 3, 4dimethoxy-N-[(2, 2-dimethyl-2H-chromen-6-yl) methyl]-N-phenylbenzenesulfonamid e, a novel small molecule hypoxia inducible factor-1(HIF-1) pathway inhibitor and anti-cancer agent., Bioorg. Med. Chem., 20 (14) 4590-4597.

8 Suresh T., Arunima V., Atin K., Sandeep G., Prarthana V. R. and Ganesh R. K. (2010) Novel chromeneimidazole derivatives as antifungal compounds: synthesis and in vitro evaluation. Acta Pol. Pharm., 67, 423-427.

9 Jain N., Xu J., Ramesh M., Du F., Jian-Zhong G., Emmanuel P., and Sui Z. (2009) Identification and Structure- Activity Relationships of Chromene-Derived Selective Estrogen Receptor Modulators for Treatment of Postmenopausal Symptoms. J. Med. Chem., 52 (23) 7544-7569.

10 Mart'inez-Grau A., and Marco J. L. (1997) Friedlander reaction on 2-amino-3-cyano-4H-pyrans: synthesis of derivates of 4Hpyran[2,3-b]quinoline, new tacrine analogues. Bioorg. Med. Chem. Lett. 7 (24) 3165-3170. 
11 Denish C. K., Hetal K. P., and Nilesh K. G. (2012) Synthesis, characterization and anti-HIV activity of 4-Hydroxy-3-(5-methylisoxazol-3-yl)pyrano(3,2-C)chromene-2,5-dione. Asian J. Biochem. Pharm. Res., 2 (2) 126-130.

12 (a) Ellis G. P. (1977) In The Chemistry of Heterocyclic of Compounds. Chromenes, Harmonesand Chromones; Weissberger, A., Taylor, E. C., Eds.; John Wiley: New York, NY,; Chapter II, pp 11e13; (b) Klocke J. A., Balandrin M. F., Adams R. P., and Kingsford E. (1985). Insecticidal chromenes from the volatile oil of Hemizonia fitchii. J. chem. eco., 11 (6) 701-712.

13 Gong K., Wang H. L., Fang D., and Liu Z. L. (2008) Basic ionic liquid as catalyst for the rapid and green synthesis of substituted 2-amino-2-chromenes in aqueous media. Catal. Commun., 9 (5) 650653.

14 Sabitha G., Bhikshapathi M., Nayak S., Srinivas R., and Yadav J. S. (2011) Triton B Catalyzed Three-Component, One-Pot Synthesis of 2-Amino-2-chromenes at Ambient Temperature. $J$. Heterocycl. Chem., 48 (2) 267-271.

15 Kidwai M., Saxena S., Khan M. K. R., and Thukral, S. S. (2005) Aqua mediated synthesis of substituted 2-amino-4H-chromenes and in vitro study as antibacterial agents. Bioorg. Med. Chem. Lett., 15 (19) 4295-4298.

16 Mirza-Aghayan M., Nazmdeh S., Boukherroub R., Rahimifard M., Tarlani A. A., and AbolghasemiMalakshah M. (2013) Convenient and Efficient One-Pot Method for the Synthesis of 2-Aminotetrahydro-4 H-chromenes and 2-Amino-4 H-benzo [h]-chromenes Using Catalytic Amount of Amino-Functionalized MCM-41 in Aqueous Media. Synth. Commun., 43 (11) 1499-1507.

17 Ballini R., Bosica G., Conforti M. L., Maggi R., Mazzacani A., Righi P., and Sartori G. (2001) Three-component process for the synthesis of 2-amino-2-chromenes in aqueous media. Tetrahedron., 57 (7) 1395-1398.

18 Jin T. S., Xiao J. C., Wang S. J., and Li T. S. (2004) Ultrasound-assisted synthesis of 2-amino-2chromenes with cetyltrimethylammonium bromide in aqueous media. Ultra. Sonochem., 11 (6) 393 397.

19 Zhou Z., Yang F., Wu L., and Zhang A. (2012) Potassium phosphate tribasic trihydrate as catalyst for the rapid and clean one-pot synthesis of 2-amino-4H-chromenes under solvent-free conditions. Chem. Sci. Trans., 1 (1) 57-60.

20 Mobinikhaledi A., Moghanian H., and Sasani F. (2011). Microwave-assisted one-pot synthesis of 2amino-2-chromenes using piperazine as a catalyst under solvent-free conditions. Synthesis and Reactivity in Inorganic. Inorg., Met. Org., Nano-Met. Chem., 41 (3) 262-265.

21 Kalla R. M. N., Byeon S. J., Heo M. S., and Kim I. (2013) Synthesis of 2-amino-3-cyano-4Hchromen-4-ylphosphonates and 2-amino-4H-chromenes catalyzed by tetramethylguanidine. Tetrahedron., 69 (49) 10544-10551.

22 Heravi M. M., Bakhtiari K., Zadsirjan V., Bamoharram F. F., and Heravi O. M. (2007) Aqua mediated synthesis of substituted 2-amino-4H-chromenes catalyzed by green and reusable Preyssler heteropolyacid. Bioorg. Med. Chem. Lett., 17 (15) 4262-4265.

23 Behbahani F. K., and Maryam S. (2013) On Water $\mathrm{CuSO}_{4} .5 \mathrm{H}_{2} \mathrm{O}$-catalyzed Synthesis of 2-amino4H-chromenes. J. Korean Chem. Soc., 57 (3) 357-360.

24 Heravi M. M., Baghernejad B. and Oskooie H. A. (2008) A novel and efficient catalyst to one-pot synthesis of 2-amino- 4H-chromenes by methanesulfonic acid. J. Chin. Biochem. Soc., 55 (3) 659662.

25 Wang X. S., Shi D. Q., Yu H. Z., Wang G. F. and Tu S. (2004) Synthesis of 2-aminochromene derivatives catalyzed by $\mathrm{KF} / \mathrm{Al}_{2} \mathrm{O}_{3}$. J. Synth. Commun., 34 (3) 509-514.

26 Dekamin M. G., Eslami M., and Maleki A. (2013) Potassium phthalimide-N-oxyl: a novel, efficient, and simple organocatalyst for the one-pot three-component synthesis of various 2 -amino- $4 \mathrm{H}$ chromene derivatives in water. Tetrahedron., 69 (3) 1074-1085.

27 Solhy A., Elmakssoudi A., Tahir R., Karkouri M., Larzek M., Bousmina M., and Zahouily M. (2010) Clean chemical synthesis of 2-amino-chromenes in water catalyzed by nanostructured diphosphate $\mathrm{Na}_{2} \mathrm{CaP}_{2} \mathrm{O}_{7}$. Green Chem., 12 (12) 2261-2267. 
28 Maleki B., and Sheikh S. (2015) Nano polypropylenimine dendrimer (DAB-PPI-G $)_{1}$ : as a novel nano basic-polymer catalyst for one-pot synthesis of 2-amino-2-chromene derivatives. RSC Adv., 5 (54) 42997-43005.

29 Raghuvanshi D. S., and Singh K. N. (2010) An expeditious synthesis of novel pyranopyridine derivatives involving chromenes under controlled microwave irradiation. ARKIVOC., 10, 305-317

30 Maleki B, and Sheikh S. (2015) One-pot Synthesis of 2-Amino-2-chromene and 2-Amino-3-cyano4H-pyran Derivatives promoted by Potassium Fluoride. Org. Prep. Proced. Int., 47 (5) 368-378.

31 Kolla S. R., and Lee Y. R. (2011) $\mathrm{Ca}(\mathrm{OH})_{2}$-mediated efficient synthesis of 2-amino-5-hydroxy-4Hchromene derivatives with various substituents. Tetrahedron., 67 (43) 8271-8275.

32 Tayebee R., Maleki B., Mohammadi Zonoz F., and Kakhi. Kunani R.M. (2016) Mild, efficient, and environmentally friendly synthesis of symmetrical $\mathrm{N}, \mathrm{N}^{\prime}$-alkylidenebisamides under solvent-free conditions catalyzed by $\mathrm{H}_{7}\left[\left(\mathrm{P}_{2} \mathrm{~W}_{17} \mathrm{O}_{61}\right) \mathrm{Fe}^{\mathrm{III}}\left(\mathrm{H}_{2} \mathrm{O}\right)\right]$. $R S C A d v$., 6 (25) 20687-20694.

33 Maleki B., Babaee S., and Tayebee R. (2015) Zn (L-Proline)2: as a powerful and reusable organomettalic catalyst for the very fast synthesis of 2-amino-4H-benzo[g]chromene derivatives under solvent-free conditions, Appl. Organomet. Chem., 29, 408-411.

34 Maleki B., Rezaei Seresht E., and Ebrahimi Z. (2015) Friedlander Synthesis of Quinolines Promoted By Polymer-bound Sulfonic Acid. Org. Prep. Proced. Int., 47, 149-160.

35 Maleki B. (2015) Solvent-free Synthesis of 2,4,6-Triarylpyridine Derivatives Promoted by 1,3Dibromo-5,5-dimethylhydantoin, Org. Prep. Proced. Int., 47, 173-178.

36 Rimaz M., Mousavi H., Keshavarz P., and Khalili, B. (2015) ZrOCl2. 8H2O as a green and efficient catalyst for the expeditious synthesis of substituted 3-arylpyrimido [4, 5-c] pyridazines in water. Curr. Chem. Lett., 4 (4) 159-168.

37 Zonouz A., Eskandari I., and Notash, B. (2015) An efficient and green procedure for the synthesis of highly substituted polyhydronaphthalene derivatives via a one-pot, multi-component reaction in aqueous media. Curr. Chem. Lett., 4 (3) 85-92.

38 Sarrafi Y., Pazokie F., Azizi S., Alimohammadi K., Mehrasbi E., and Chiani E., (2014) Mesoporous SBA-15 nanoparticles: An efficient and eco-friendly Catalyst for one-pot synthesis of 3, 4dihydropyrimidin-2 (1H)-ones under solvent-free conditions. Curr. Chem. Lett., 3 (2) 97-102.

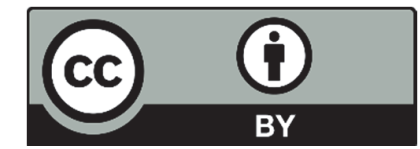

(C) 2016 by the authors; licensee Growing Science, Canada. This is an open access article distributed under the terms and conditions of the Creative Commons Attribution (CC-BY) license (http://creativecommons.org/licenses/by/4.0/). 